\title{
EFFECTS OF COKE ON GERMINATION AND GROWTH OF VIGNA RADIATA (L.) R. WILCZEK, VIGNA MUNGO (L.) HEPPER AND VIGNA UNGUICULATA (L.) WALP.
}

\author{
Rasheeda JAMALI ${ }^{1}$, Muhammad ZAFAR IQBAL ${ }^{1}$, Muhammad SHAFIQ ${ }^{{ }^{*}}$ \\ ${ }^{1}$ Department of Botany, University of Karachi, Karachi - Pakistan. \\ * Corresponding author. E-mail: shafiqeco@yahoo.com
}

\begin{abstract}
Coke production is one of the important sources of pollution from steel industries. The effects of coke (sludge of iron and steel) on seed germination and growth of Vigna radiata (L.) R. Wilczek, Vigna mungo (L.) Hepper and Vigna unguiculata (L.) Walp. were recorded. The seed germination percentage of $V$. radiata was increased with increase in coke concentration treatment at $25-50 \%$ as compared to control treatment in petri dish. Seedling length and root growth performance of $V$. radiata was also slightly increased with the increase in coke concentration treatment at 75 and $100 \%$ as compared to control. The seed germination percentage and root length of $V$. mungo was reduced with increase in coke concentration treatment at $25 \%$. The obtained results showed more positive effects of coke on seed germination and seedling growth performance of $V$. unguiculata than $V$. mungo and $V$. radiata. Meanwhile, experiment showed decrease in seedling vigor index of $V$. radiata and $V$. mungo with the increase in concentration of coke at $100 \%$ as compared to control. A gradual increase in seedling vigor index for V. unguiculata with the increase in coke concentration was observed. The coke extracts treatment influence on the seedling tolerance indices of $V$. radiata, $V$. mungo and $V$. unguiculata. The better tolerance to coke treatment in all bean crops might be mainly due to some resistance potential ability of seedlings to coke concentration.
\end{abstract}

Keywords: Bean crop, coke, ecotoxicity, seedling vigor index, tolerance.

\section{Introduction}

Naturally found coal is converted to coke which is suitable for metallurgical industries [GHOSE, 2002]. Cokes wastewater has been considered the most toxic one to be treated before being discharged into the environments [LEE \& PARK, 1998; ZHANG \& al. 1998]. Steel industries generate various wastewaters during the manufacture and processing of iron [KIM \& al. 2007]. Significant quantities of sludge and slag are generated as waste material or byproduct every day from steel industries. They usually contain considerable quantities of metals and other materials [DAS \& al. 2007]. Steel is one of the most utilized and recycled materials within the global economy [ZHANG \& al. 2009]. The iron and steel industry have generated significant amounts of hazardous waste and has emitted vast quantities of toxic pollutants into the atmosphere. Metal dusts, slag, carbon monoxide, nitrogen oxides, and ozone are examples of substances generated during the steel making process and coke oven emissions contain harmful substances like polycyclic aromatic hydrocarbons (PAHs), volatile organic compounds (VOCs), benzene, particulate matter, and dioxins [ROSENFELD \& FENG, 2011]. The production of coke is an integral component of the steel manufacturing process [WALSH \& THORNLEY, 2012]. Industrial activities, including iron steel metallurgy, are major source of atmospheric heavy metals emissions like copper $(\mathrm{Cu})$, zinc $(\mathrm{Zn})$, nickel $(\mathrm{Ni})$, lead $(\mathrm{Pb})$, chromium $(\mathrm{Cr})$ and cadmium (Cd) [BOLONIAZ \& BULINSKI, 1984; GRITSAN \& BABIY, 2000; KAMINSKI \& LANDSBERGER, 2000; ADAMO \& al. 2002; SALEMAA \& al. 2001; VENDITTI \& al. 2000; 
SHAFIQ \& IQBAL, 2012; SHAFIQ \& al. 2019]. These toxic airborne metals settle on soil surfaces and vegetation canopies [KADEM \& al. 2004].

The iron and steel industry are a resource and energy intensive industry [MA \& al. 2014] and an important source of high level of pollution and emissions [LIU \& al. 2014]. There are few reports available on the effects of coke on germination and growth of plants. Coke oven emissions are known as human carcinogen, which is a complex mixture of polycyclic aromatic hydrocarbon [ZHAI \& al. 2012]. Coke is used chiefly to smelt iron ore and other iron bearing materials in blast furnaces, acting both as a source of heat and as a chemical reducing agent, to produce pig iron, or hot metal [AVIDSYS, 2021]. Coking is one of the most important emission sources of (PAHs) polycyclic aromatic hydrocarbons (PAHs) [MU \& al. 2014]. Coke oven emissions contain literally several thousand compounds, several of which are known carcinogens and/or cocarcinogens (including polycyclic organic matter from coal tar pitch volatiles, beta-naphthylamine, benzene, arsenic, beryllium, cadmium, chromate, lead, nickel sub sulfide, nitric oxide and sulfur dioxide [GRAHAM \& HOLTGRAVE, 2014].

An external and internal factor, ranging from soil humidity, diseases, pests, competition, and pollutants to individual genes and plant age influence plant phenology [MENZEL, 1999]. The growth and physiological effects of coke on Triticum aestivum and Deschampsia caespitosa in a greenhouse study showed the stress symptoms such as reductions in transpiration $(45-91 \%)$ and stomatal conductance rates (44-92\%) in T. aestivum, biomass in T. aestivum (5-83\%) and D. caespitosa (43-90\%), photosynthetic pigments in T. aestivum (32-68\%) and D. caespitosa (33$44 \%$ ) and proline concentrations in D. caespitosa (77-97\%) observed [NAKATA \& al. 2011]. The impact of industrial effluent from 4 different surface treatment companies using seeds of the lettuce Lactuca sativa were measured for bioassay test. The results were used to compare the overall toxicity of the different effluents containing copper, nickel, zinc and aluminum. The germination tests confirmed that mixtures of metals have higher toxicity than the sum of their separate constituents. These biological tests are found cheap, easy to implement, reproducible and highlight the effects caused by effluent treated with the methods commonly applied in industry today [CHARLES \& al. 2011]. Plant growth and development can be highly restricted by environmental stressors such as cadmium $(\mathrm{Cd})$ pollution. The effects of environmentally realistic Cd exposure $(5$ and $10 \mu \mathrm{M})$ on the alternative respiratory chain in Arabidopsis thaliana using a kinetic exposure setup was reported [KEUNEN \& al. 2013]. The effects of atmospheric PMselected components (brake dust - BD, pellet ash - PA, road dust - RD, certified urban dust NIST1648a - NIST, soil dust - S, coke dust - C) affected the root morphology of Arabidopsis thaliana development due to inducive oxidative stress [PIACENTINI \& al. 2019].

Vigna genus has wide distributions in tropical areas of the world along with many species likewise Vigna radiata (L.) R. Wilczek, Vigna mungo (L.) Hepper and Vigna unguiculata (L.) Walp. The behavior of 6 genotypes of cowpea (Vigna unguiculata (L.) Walp. and 5 genotypes of mung beans (Vigna radiata (L.) R. Wilczek), of Chinese origin, in comparison with the indigenous cowpea genotype, Aura 26 in the conditions of the sandy soils of SCDCPN Dăbuleni, between 2016-2018 in Romania was carried out in sandy soil. The physiology of the studied plant species revealed a better adaptability of the genotypes of cowpea as compared to mung beans. The obtained results at the harvest level showed the production of grains in the range of $670-2511.9 \mathrm{~kg} / \mathrm{ha}$ in the cowpea genotypes and 1861.9-2209.5 kg/ha at the genotypes in the mung beans [DRĂGHICI \& al. 2019].

The coke productions play an important role in steel industries. Coke release high concentration of toxic pollutants in the environment and can inhibit or decrease the germination and growth of plants. Many researchers have drawn their attention on the effects of coke on 
Rasheeda JAMALI \& al.

plant growth. Vigna radiata (L.) R. Wilczek, Vigna mungo (L.) Hepper and Vigna unguiculata (L.) Walp. are an important legume crops and cultivated in larger area of Pakistan. Therefore, the objective of this study was to investigate the effects of coke on seed germination and seedling growth of crops by using different levels of coke and compared it with control.

\section{Material and methods}

The coke sample (sludge of iron and steel) was collected from Pakistan steel mill, Karachi, Pakistan. Pakistan steel mill is one of the enormous and gigantically expanded industrial complex in the country that is located at a distance of $40 \mathrm{~km}$ Southeast of Karachi at Bin Qasim near Port Muhammad Bin Qasim. It is one of the largest industrial complexes in Pakistan as well as in South Asia.

The composition of coke was high fixed carbon (80-85\%), low ash (10-15\% ash), low volatile matter ( $2 \%$ maximum) and low phosphorous ( $0.3 \%$ maximum). The seeds of Vigna radiata (L.) R. Wilczek, Vigna mungo (L.) Hepper and Vigna unguiculata (L.) Walp. were obtained for the experiment from the local market. The petri dishes and filter paper were sterilized in an autoclave to prevent microbial contamination. The seeds were imbibed for half an hour to break the dormancy of seed and then transferred into medium sized petri dishes on Whatman filter paper. In each petri dish ten seed were placed. Seed germination was tested on moist filter paper. $10 \mathrm{~g}$ coke was added in $100 \mathrm{ml}$ distilled water and that mixture was kept for 24 hours and then filtered. This filtered solution was assumed to be the standard solution which was $100 \%$. From this standard solution further dilution $25 \%, 50 \%, 75 \%$ and $100 \%$ were made in distilled water. Distilled water was used as control for the experiments. Each treatment had three replicates. Initially, seeds were treated with $5 \mathrm{ml}$ of respective extract solution and later replaced with $2 \mathrm{ml}$ of fresh extract solution on alternate days. Controls were maintained by moisting the filter paper with $5.0 \mathrm{ml}$ distilled water. All petri dishes were kept in dark for seed germination and later on shifted in light (200 volts). Germination percentage was recorded daily. Seedlings were removed from the petri dishes after 10 days growth. Three best seedlings were selected from each Petri dish for mean values. The experimental design was completely randomized. Growth parameter in terms of root, shoot and seedling length were measured with the help of meter scale. The seedlings were dried in an oven at $80{ }^{\circ} \mathrm{C}$ for 24 hours until the seedlings were completely oven dried. The seedling vigor index was also determined according to BEWLY \& BLACK (1982) and Tolerance indices of seedlings were determined with the help of following formula:

Tolerance Indices = Mean root length of coke extract $/$ Mean root length of control without coke extract $\times 100$

The data obtained were statistically analyzed on personnel computer using COSTAT version 3 .

\section{Results}

The effects of different concentration $(0,25,50,75$ and 100\%) of coke extract on seed germination and seedling growth of three different bean crops viz. Vigna radiata, Vigna mungo and Vigna unguiculata were recorded (Table 1; Figures 1-2). Seed germination of V. radiata did not show any significant changes on seed germination percentage when treated with different concentration of coke as compared to control. Coke extract treatment at 25 and $50 \%$ increased the rate of seed germination in V. radiata as compared to control. Coke treatment at 
25, 50, 75 and $100 \%$ showed $100 \%, 100 \%, 90$ and $96.66 \%$ rate of seed germination in $V$. radiata as compared to control $(96.66 \%)$. The coke treatment not showed any significant $(\mathrm{p}<0.05)$ sign of phytotoxicity on root, shoot, seedling growth and root / shoot ratio of $V$. radiata as compared to control treatment (Table 1).

The effects of different concentration of coke extract treatment on seed germination, root, shoot, seedling length, root / shoot ratio and seedling dry weight of $V$. mungo were observed (Table 1). Increasing concentration of coke at (25\%) decreased seed germination percentage (90\%) of V. mungo as compared to control. Low percentage of seed germination (96.66\%) also found at $100 \%$ coke treatment as compared to control (100\%). Coke treatment at all level showed no significant changes in root, shoot and seedling length and seedling dry weight of $V$. mungo as compared to control. Similar to seed germination, root, shoot and seedling length was decreased at $100 \%$ coke extract treatment as compared to control. It was observed that coke treatment at $25 \%$ showed significant $(\mathrm{p}<0.05)$ changes in root / shoot ratio of $V$. mungo.

A pronounced effect in seed germination percentage, root, shoot, seedling length, seedling dry weight and root / shoot ratio of $V$. unguiculata was found in response to different concentration of coke extract treatment as compared to control (Table 1). There was an increase in seed germination percentage of $V$. unguiculata with increasing coke extract treatment. Seed germination of $V$. unguiculata was significantly $(\mathrm{p}<0.05)$ increased in $25 \%$ to $100 \%$ coke extract treatment by $73.33 \%, 90 \%, 76.66 \%$ and $86.66 \%$ ) as compared to control (40\%), respectively. Coke extract treatment at all concentration did not show any significant effects in shoot growth of $V$. unguiculata as compared to control. Root growth of $V$. unguiculata was found significantly increased in coke extract treatment at $50 \%(9.36 \mathrm{~cm})$ as compared to control $(5.60 \mathrm{~cm})$. A significant result on seedling dry weight of $V$. unguiculata by $25 \%$ concentration of coke treatment was observed. Root shoot ratio significantly affected by $25 \%$ coke treatment.

Table 1. Effects of different concentrations of coke extract (0, 25, 50, 75 and 100\%) on seed germination, seedling growth and yield of some bean crops (Vigna radiata, Vigna mungo and Vigna unguiculata)

\begin{tabular}{|c|c|c|c|c|c|c|c|}
\hline $\begin{array}{l}\text { Crop } \\
\text { species }\end{array}$ & $\begin{array}{c}\text { Coke } \\
\text { Treatments } \\
(\%)\end{array}$ & $\begin{array}{l}\text { SG } \\
(\%)\end{array}$ & $\begin{array}{c}\text { Root } \\
\text { length } \\
(\mathbf{c m})\end{array}$ & $\begin{array}{c}\text { Shoot } \\
\text { length } \\
(\mathrm{cm})\end{array}$ & $\begin{array}{c}\text { Seedling } \\
\text { size } \\
(\mathrm{cm})\end{array}$ & $\begin{array}{c}\text { Root/shoot } \\
\text { Ratio }\end{array}$ & $\begin{array}{l}\text { Seedling dry } \\
\text { weight } \\
\text { (g) }\end{array}$ \\
\hline \multirow{5}{*}{ 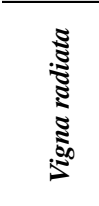 } & 00 & $96.66 \mathrm{a} \pm 3.3$ & $6.73 a \pm 1.6$ & $18.66 \mathrm{a} \pm 1.2$ & $25.46 a \pm 2.6$ & $0.35 a \pm 0.06$ & $0.026 \mathrm{ab} \pm 0.0$ \\
\hline & 25 & $100.00 \mathrm{a} \pm 0.0$ & $7.80 \mathrm{a} \pm 2.0$ & $17.76 \mathrm{a} \pm 1.4$ & $25.56 a \pm 3.3$ & $0.42 \mathrm{a} \pm 0.08$ & $0.020 \mathrm{a} \pm 0.0$ \\
\hline & 50 & $100.00 \mathrm{a} \pm 0.0$ & $5.40 \mathrm{a} \pm 0.4$ & $21.03 a \pm 0.7$ & $26.460 \mathrm{a} \pm 0.4$ & $0.25 \mathrm{a} \pm 0.02$ & $0.036 b \pm 0.0$ \\
\hline & 75 & $90.00 \mathrm{a} \pm 5.8$ & $8.36 \mathrm{a} \pm 1.4$ & $21.86 a \pm 1.8$ & $30.30 \mathrm{a} \pm 2.6$ & $0.38 \mathrm{a} \pm 0.06$ & $0.026 \mathrm{ab} \pm 0.0$ \\
\hline & 100 & $96.66 \mathrm{a} \pm 3.3$ & $7.10 \mathrm{a} \pm 0.6$ & $19.43 \mathrm{a} \pm 1.3$ & $26.53 a \pm 1.8$ & $0.35 \mathrm{a} \pm 0.02$ & $0.016 \mathrm{a} \pm 0.0$ \\
\hline \multirow{5}{*}{ 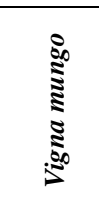 } & 00 & $100.00 \mathrm{a} \pm 0.0$ & $7.85 \mathrm{a} \pm 0.5$ & $16.50 \mathrm{a} \pm 2.5$ & $24.30 \mathrm{a} \pm 2.0$ & $0.49 \mathrm{ab} \pm 0.1$ & $0.030 \mathrm{a} \pm 0.000$ \\
\hline & 25 & $90.00 \mathrm{a} \pm 5.8$ & $6.70 \mathrm{a} \pm 0.3$ & $17.56 \mathrm{a} \pm 1.2$ & $24.26 \mathrm{a} \pm 0.9$ & $0.38 \mathrm{a} \pm 0.08$ & $0.023 a \pm 0.003$ \\
\hline & 50 & $100.00 \mathrm{a} \pm 0.0$ & $8.76 \mathrm{a} \pm 0.8$ & $15.70 \mathrm{a} \pm 1.2$ & $24.53 \mathrm{a} \pm 1.9$ & $0.55 b \pm 0.02$ & $0.026 a \pm 0.003$ \\
\hline & 75 & $90.00 \mathrm{a} \pm 5.8$ & $6.66 \mathrm{a} \pm 1.1$ & $17.96 a \pm 0.6$ & $24.70 \mathrm{a} \pm 1.7$ & $0.36 \mathrm{a} \pm 0.06$ & $0.023 a \pm 0.003$ \\
\hline & 100 & $96.66 \mathrm{a} \pm 3.3$ & $7.66 \mathrm{a} \pm 0.3$ & $16.10 \mathrm{a} \pm 0.4$ & $23.83 a \pm 0.5$ & $0.47 \mathrm{ab} \pm 0.0$ & $0.020 \mathrm{a} \pm 0.005$ \\
\hline \multirow{5}{*}{ 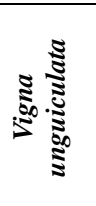 } & 00 & $40.00 \mathrm{a} \pm 10.0$ & $5.60 \mathrm{ab} \pm 0.3$ & $11.05 \mathrm{a} \pm 0.3$ & $16.60 \mathrm{a} \pm 0.0$ & $0.50 \mathrm{ab} \pm 0.04$ & $0.045 \mathrm{a} \pm 0.01$ \\
\hline & 25 & $73.33 b \pm 3.3$ & $5.83 \mathrm{ab} \pm 0.2$ & $14.20 \mathrm{a} \pm 1.2$ & $20.06 \mathrm{ab} \pm 1.2$ & $0.41 \mathrm{a} \pm 0.03$ & $0.096 \mathrm{~b} \pm 0.00$ \\
\hline & 50 & $90.00 \mathrm{~b} \pm 5.8$ & $9.36 c \pm 0.6$ & $14.13 \mathrm{a} \pm 2.4$ & $23.53 b \pm 2.8$ & $0.68 c \pm 0.08$ & $0.080 \mathrm{ab} \pm 0.01$ \\
\hline & 75 & $76.66 \mathrm{~b} \pm 6.7$ & $4.50 \mathrm{a} \pm 0.3$ & $10.40 \mathrm{a} \pm 1.1$ & $14.96 a \pm 1.2$ & $0.44 a \pm 0.05$ & $0.066 \mathrm{ab} \pm 0.01$ \\
\hline & 100 & $86.66 \mathrm{~b} \pm 8.8$ & $6.46 b \pm 0.8$ & $10.06 \mathrm{a} \pm 1.0$ & $16.53 \mathrm{a} \pm 1.8$ & $0.63 b c \pm 0.01$ & $0.090 \mathrm{~b} \pm 0.01$ \\
\hline
\end{tabular}

Number followed by the same letters in the same column are not significantly different according to Duncan Multiple Range Test at $<0.05$ level. \pm Standard Error, $S G=$ Seed germination 
Rasheeda JAMALI \& al.

A positive increase and decrease in tolerance index in seedlings of bean crops to different concentrations of coke extract treatment was recorded (Figure 1). The lowest tolerance indices $84.84 \%$ and $80.35 \%$ in seeding of $V$. mungo and $V$. unguiculata was recorded with the coke treatment at $76 \%$ as compared to control. An increase in concentration of coke treatment at $100 \%$ showed better tolerance index $105.49 \%$ and $115.35 \%$ in seedlings of $V$. radiata and $V$. unguiculata as compared to control.

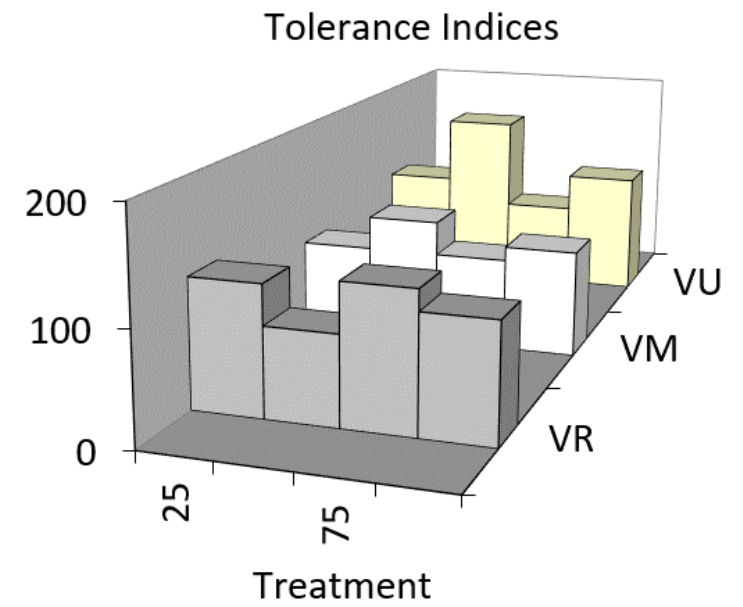

Figure 1. Tolerance indices of seedlings of bean crops $(\mathrm{VR}=$ Vigna radiata, $\mathrm{VM}=$ Vigna mungo and $\mathrm{VU}=$ Vigna unguiculata $)$ at different concentration of coke extract 25, 50, 75 and 100\%

\section{Seedling Vigor Index}

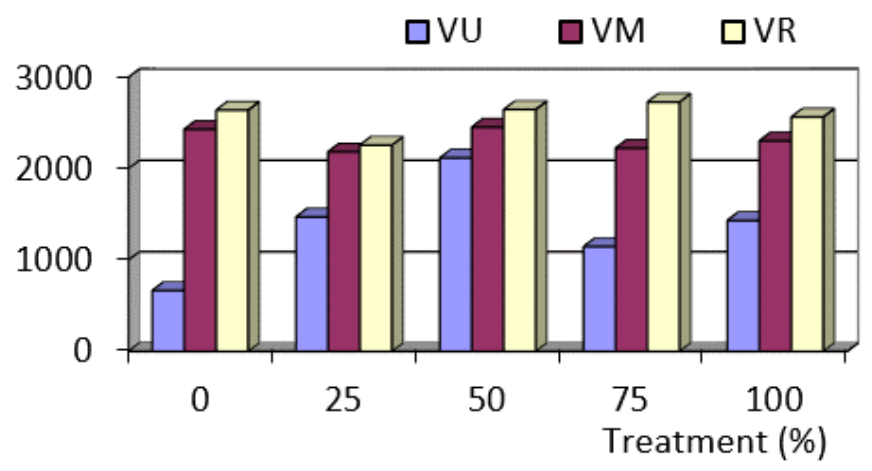

Figure 2. Seedling Vigor Index (S.V.I.) of seedlings of bean crops (VR = Vigna radiata, VM = Vigna mungo and $\mathrm{VU}=$ Vigna unguiculata $)$ at different concentration of coke extract $(0,25,50,75$ and 100\%)

eedling vigor index (SVI) is the potential of seed germination and seedling size against the toxicity and tolerance of coke extract having pollutant. Results indicate a decreasing trend of SVI in seedlings obtained through different concentrations of coke treatment, when compared with control. It was found that the coke extract treatment affected on seedling vigor index of $V$. radiata, V. mungo and $V$. unguiculata (Figure 2). Seed germination and seedling growth tests 
using different concentration of coke extract on crop bean showed different response of seedling vigor index. Max seedling vigor index (2641) was found in control seedlings of $V$. radiata was found. Low seedling vigor index (2564) was found in seedlings of $V$. radiata at $100 \%$ coke treatment. Reduced seedling vigor index possessed by $V$. mungo with increasing concentration of coke dust is probably due to less tolerance. Retardation in seedling length in $V$. mungo due to toxic concentrations of coke extract may be an important reason for reduction in seedling vigor index at $100 \%$ coke treatment.

\section{Discussion}

Coke is an important raw material in the iron and steel industry [BOND \& al. 2013]. Present study revealed the toxic effects of coke on germination and growth of some bean crops species viz. V. radiata, $V$. mungo and $V$. unguiculata mainly due to high concentrations of coke extract treatment as compared to control. Comparative analysis of the obtained data using different growth parameters (seed germination, root, shoot and seedling length, root / shoot ratio, seedling dry weight, seedling vigor index and tolerance indices) of $V$. radiata, $V$. mungo and $V$. unguiculata can allow the validation on understanding the toxic nature of coke as a pollutant. Coke extract treatment produced positive and negative effects on the growth of selected bean crop species as compared to non coke extract treated plants. Germination and early seedling growth have been regarded as critical phases, which are greatly influenced by stressful conditions [SHAH \& DUBEY, 1995]. Concerning the impact of coke dust pollution on seed germination percentage of $V$. radiata, the same trend detected in the reduction in seed germination of $V$. mungo. Whereas, coke treatment at all concentration increased the seed germination percentage of $V$. unguiculata which might be due to its tolerance to coke extract to some extent as compared to control. Reduction in plant height of $V$. mungo and $V$. unguiculata showed that the losses generally can be attributed to the coke extract treatment which contained toxic metals. Coke concentration added at higher concentrations $(100 \%)$ produced significant $(\mathrm{p}<0.05)$ impact on seedling growth performance of $V$. unguiculata as compared to control. Similarly, Petro-coke treatment at the rate of $2 \mathrm{~g}$ petro coke $\mathrm{m}^{-2} \mathrm{~d}^{-1}$ for $65 \mathrm{~d}$ age of green gram (Phaseolus aureus) plants with respect to transpiration rate, mineral accumulation, and contents of ascorbic acid, protein, carbohydrate, pigments, root and shoot lengths, number of leaves, nodules, flowers, and pods were found reduce in Petro-coke-treated plants [PRASAD \& RAO, 1981].

In present studies the seed germination and seedling growth elongation tests using as seedling vigor index for all bean crop showed variation in seedling indices value as compared to control. The study reported herein reveals that the reductions in seedling dry weight of $V$. radiata, $V$. mungo and $V$. unguiculata was due to reduction in root and shoot growth as the concentration of coke treatment increased in substrate as compared to control. Growth characteristics such as root shoot and seedling length decreased and treated seedlings of bean crops. The seedling vigor index of V. radiata (2564) and V. mungo (2303) was highly decreased with $100 \%$ coke treatment as compared to control 2640 and 2430, respectively. This effect was dose dependent, and was more significant at higher concentration as compared to control. The effect of steel factory effluent on seed germination and seedling, growth of Phaseolus mungo cv. T-9, showed that increasing concentration of effluent induced a gradual decrease in germination percentage [KUMAR, 2006]. 


\section{Conclusion}

Overall results showed that germination and growth of two Vigna species $V$. radiata and $V$. mungo was not significantly $(\mathrm{p}<0.05)$ affected by all levels of coke concentration treatment as compared to control. Coke treatment was found most toxic for $V$. unguiculata seedlings than $V$. radiata and $V$. mungo. The study of plant behavior in coke pollution allows the identification and selection of pollution indicating species. On the basis of this study, it could be concluded that seedling growth of $V$. unguiculata was found to be more affected than $V$. radiata and $V$. mungo by coke pollution, which might be due to the presence of different toxic pollutants in coke. V. unguiculata was found highly affected by coke treatment. V. mungo was found moderately affected, while, $V$. radiata was found less affected by coke application. It is suggested that the variation in the seedling growth parameter of bean crops might be used as tolerance indicator for pollution by coke. The coke treatment induced decrease in growth of Vigna unguiculata plants may be due to toxic pollutants present in the medium and their interference with seedling growth and reducing its growth rate which in turn affects the uptake of water and this influences growth of the entire plant resulting in biomass production. Furthermore, this study can be helpful in building a baseline data for future long term field studies essential for developing coke management guidelines.

\section{Notes on contributors}

Rasheeda JAMALI, MSc., is botanist and research scientist with special interest in plant ecology and impact of industrial pollution on plant growth.

Professor Dr. Muhammad Zafar IQBAL Ph.D. is ex chairman Department OF Botany, University OF Karahi, Pakistan. The area of research interest are plant ecology, sociology, dynamic ecology, climatology, soil science and environmental pollution. Dr. M. Z. Iqbal has published 200 scientific research papers in national and international scientific peer reviewed renowned scientific journals and supervised 58 research project/ thesis.

Dr. Muhammad SHAFIQ Ph.D. is a research scholar with area of research interest on the plant ecology/environmental pollution/heavy metal toxicity and tolerance in plants and seedling growth behavior of plants. Dr. M. Shafiq has published more than 110 scientific research papers in national and international scientific peer reviewed renowned scientific journals. He has also published two books on "Impact of Automobile Pollutants on Plants" and "Poison Land, "Vegetation of disturbed and polluted areas in Pakistan".

\section{Acknowledgements}

We are thankful to the chairperson, Department of Botany and the University authorities for providing us space and facilities for conducting this research.

\section{References}

ADAMO P., DUDKA S., WILSON M. J. \& McHARDY W. J. 2002. Distribution of trace elements in soils from the Sudbury smelting area (Ontario, Canada). Water, Air and Soil Pollution. 137: 95-116. https://doi.org/10.1023/A:1015587030426

AVIDSYS. 2021. Coke production process. http://www.avidsys.com.au/metallurgicalcoal. Visited on 14-12-2021.

BEWLY J. D. \& BLACK B. M. 1982. Germination of seeds. In: KHAN A. A. (ed.). 1982. Physiology and biochemistry of seed germination. Springer Verlag, NewYork, pp. 40-80.

BOLONIAZ J. \& BULINSKI R. 1984. Effect of dust emission in the area of steel and electric power plants on various trace elements contents of selected vegetables and fruit - I: lead, cadmium, zinc, nickel and iron contents of vegetables. Roczniki Państwowego Zakładu Higieny. 35(2): 29-35.

BOND T. C., DOHERTY S. J., FAHEY D. W., FORSTER P. M., BERNTSEN T., DEANGELO B. J., FLANNER M. G., GHAN S., KÄRCHER B., KOCH D., KINNE S., KONDO Y., QUINN P. K., SAROFIM M. C., 
SCHULTZ M. G., SCHULZ M., VENKATARAMAN C., ZHANG H., ZHANG S., BELLOUIN N., GUTTIKUNDA S. K., HOPKE P. K., JACOBSON M.Z., KAISER J. W., KLIMONT Z., LOHMANN U., SCHWARZ J. P., SHINDELL D., STORELVMO T., WARREN S. G. \& ZENDER C. S. 2013. Bounding the role of black carbon in the climate system: A scientific assessment. Journal of Geophysical Research: Atmospheres. 118(11): 5380-5552. https://doi.org/10.1002/jgrd.50171

CHARLES J., SANCEY B., MORIN-CRINI N, BADOT P., DEGIORIGI F., TRUNFIO G. \& CRINI G. 2011. Evaluation of the phytotoxicity of polycontaminated industrial effluents using the lettuce plant (Lactuca sativa) as a bioindicator. Ecotoxicology and Environmental Safety. 74(7): 2057-2064. https://doi.org/10.1016/j.ecoenv.2011.07.025

DAS B., PRAKASH S., REDDY P. S. R. \& MISRA V. N. 2007. An overview of utilization of slag and sludge from steel industries. Resources, Conservation and Recycling. 50(1): 40-57.

GHOSE M. K. 2002. Complete physico-chemical treatment for coke plant effluents. Water Research. 36(5): 1127-1134. https://doi.org/10.1016/s0043-1354(01)00328-1

GRAHAM J. D. \& HOLTGRAVE D. R. 2014. Coke oven emission: A case study of technology based regulation. RISK: Health, Safety \& Environment. 1(3): 243-272.

GRITSAN N. P. \& BABIY A. P. 2000. Hazardous materials in the environment of Dnepropetrovsk region (Ukraine). Journal of Hazardous Materials. 76(1): 59-70. https://doi.org/10.1016/s0304-3894(00)00210-7

KADEM D. E. D., RACHED O., KRIKA A. \& GHERIBI-AOULMI Z. 2004. Statistical analysis of vegetation incidence on contamination of soils by heavy metals $(\mathrm{Pb}, \mathrm{Ni}$ and $\mathrm{Zn})$ in the vicinity of an iron steel industrial plant in Algeria. Environmetrics. 15(5): 447-462. https://doi.org/10.1002/env.673

KAMINSKI M. D. \& LANDSBERGER S. 2000. Heavy metals in urban soil of East St. Louis, IL, Part I: total concentration of heavy metals in soils. Journal of the Air \& Waste Management Association. 50(9): 16801687. https://doi.org/10.1080/10473289.2000.10464190

KEUNEN E., JOZEFCZAK M., REMAN T., VANGRONSVELD J. \& CUYPERS A. 2013. Alternative respiration as a primary defence during cadmium-induced mitochondrial oxidative challenge in Arabidopsis thaliana. Environmental and Experimental Botany. 91: 63-73. https://doi.org/10.1016/j.envexpbot.2013.02.008

KIM Y. M., PARK D., LEE D. S. \& PARK J. M. 2007. Instability of biological nitrogen removal in a cokes wastewater treatment facility during summer. Journal of Hazardous Materials. 141(1): 27-32. https://doi.org/10.1016/j.jhazmat.2006.06.074

KUMAR S. 2006. Effect of the steel factory effluent on the seed germination and seedling growth of Phaseolus mungo CV.T-9. Advances Plant Sciences. 19(1): 277-283

LEE M. W. \& PARK J. M. 1998. Biological nitrogen removal from coke plant wastewater with external carbon addition. Water Environment Research. 70(5): 1090-1095. https://doi.org/10.2175/106143098X123444

LIU L., LM K., MEHMUD M., WEICHENTHAL S., CAKMAK S., SHUTT R., YOU H., THOMSON E., VINCENT R., KUMARATHASAN P., BROAD G. \& DALES R. 2014. Exposure to air pollution near a steel plant and effects on cardiovascular physiology: A randomized crossover study. International Journal of Hygiene Environmental Health. 217(2-3): 279-286. https://doi.org/10.1016/j.ijheh.2013.06.007

MA S., WEN Z. \& NING J. 2014. Mode of circular economy in China's iron and steel industry: a case study in Wu'an city. Journal of Cleaner Production. 64: 505-512. https://doi.org/10.1016/j.jclepro.2013.10.008

MENZEL A. 1999. Veränderungen der phänologischen Jahreszeiten. In: Wetterdienst Deutscher (ed.) Klimastatusbericht. Offenbach am Main: Deutscher Wetterdienst. pp. 99-106.

MU L., PENG L., LIU X., SONG C., BAI H., ZHANG J., HU D., HE Q. \& LI F. 2014. Characteristics of polycyclic aromatic hydrocarbons and their gas/particle partitioning from fugitive emissions in coke plants. Atmospheric Environment. 83: 202-210. https://doi.org/10.1016/j.atmosenv.2013.09.043

NAKATA C., QUALIZZA C., MACKINNON M. \& RENAULT S. 2011. Growth and physiological responses of Triticum aestivum and Deschampsia caespitosa exposed to petroleum coke. Water, Air and Soil Pollution. 216(1-4): 59-72.

PIACENTINI D., FALASCA G., CANEPARI S. \& MASSIMI L. 2019. Potential of PM-selected components to induce oxidative stress and root system alteration in a plant model organism. Environment International. 132: 105094. https://doi.org/10.1016/j.envint.2019.105094

PRASAD B. J. \& RAO D. N. 1981. Growth responses of Phaseolus aureus plants to petro-coke pollution. Journal of Experimental Botany. 32(6): 1343-1350. https://doi.org/10.1093/jxb/32.6.1343

ROSENFELD P. E. \& FENG L. G. H. 2011. Risk of Hazardous Waste. Elsevier, Amsterdam, Boston, New York. publisher. 448 pp. The Boulevard, Long ford Lane, Kidlington, Oxford, UK. https://doi.org/10.1016/C2009$0-62341-2$

SALEMAA M., VANHA-MAJAMAA I. \& DEROME J. 2001. Understorey vegetation along a heavy-metal pollution gradient in S.W. Finland. Environmental Pollution. 112(3): 339-350. https://doi.org/10.1016/s02697491(00)00150-0 
Rasheeda JAMALI \& al.

SHAFIQ M. \& IQBAL M. Z. 2012. Impact of Automobile Pollutants on Plants. LAMBERT Academic Publishing GmbH \& Co. KG Heinrich-Böcking-Str. 6-8, 66121, Saarbrücken, Germany, 132 pp.

SHAFIQ M., IQBAL M. Z., KABIR M. \& FAROOQI Z. U. 2019. Poison Land. Vegetation of disturbed and polluted areas in Pakistan. Strategic book publishing \& rights agency, U.S.A., 173 pp.

SHAH K. \& DUBEY R. S. 1995. Effect of cadmium on RNA level as well as activity and molecular forms of ribonuclease in growing rice seedlings. Plant Physiology and Biochemistry. 33: 577-584.

VENDITTI D., DURECU S. \& BERTHELIN J. 2000. A multidisciplinary approach to assess history, environmental risks, and remediation feasibility of soils contaminated by metallurgical activities - Part A: chemical and physical properties of metals and leaching ability. Archives of Environmental Contamination and Toxicology. 38: $411-420$.

WALSH C. \& THORNLEY P. 2012. The environmental impact and economic feasibility of introducing an Organic Rankine Cycle to recover low grade heat during the production of metallurgical coke. Journal of Cleaner Production. 34: 29-37. https://doi.org/10.1016/j.jclepro.2011.12.024

ZHAI Q., DUAN H., WANG Y., HUANG C., NIU Y., DAI Y., BIN P., LIU Q., CHEN W., MA J. \& ZHENG Y. 2012. Genetic damage induced by organic extract of coke oven emissions on human bronchial epithelial cells. Toxicology in Vitro. 26(5): 752-758. https://doi.org/10.1016/j.tiv.2012.04.001

ZHANG M., TAY J. H., QIAN Y. \& GU X. S. 1998. Coke plant wastewater treatment by fixed biofilm system for COD and $\mathrm{NH}_{3}-\mathrm{N}$ removal. Water Research. 32(2): 519-527.

ZHANG X., JIANG W., DENG S. \& PENG K. 2009. Energy evaluation of the sustainability of Chinese steel production during 1998-2004. Journal of Cleaner Production. 17(11): 1030-1038. https://doi.org/10. 1016/j.jclepro.2009.02.014

\section{How to cite this article:}

JAMALI R., ZAFAR IQBAL M. \& SHAFIQ M. 2021. Effects of coke on germination and growth of Vigna radiata (L.) R. Wilczek, Vigna mungo (L.) Hepper and Vigna unguiculata (L.) Walp. J. Plant Develop. 28: 129-137. https://doi.org/10.47743/jpd.2021.28.1.877 